\title{
Promoting and Maintaining Bilingualism and Biliteracy: Cognitive and Biliteracy Benefits \& Strategies for Monolingual Teachers
}

\author{
Debra A. Giambo* and Tunde Szecsi
}

Florida Gulf Coast University, Fort Myers, FL, USA

\begin{abstract}
Many school personnel pursue the goal of developing English language learners' English-language and literacy skills efficiently and this is most often implemented to the exclusion of supporting, developing, and maintaining students' heritage language skills. However, there is significant evidence that promoting bilingualism and biliteracy can significantly contribute to the effect that many school personnel want, that of efficiently developed English language and literacy skills, with the added benefit of students who can function and thrive in multilingual environments. In this article, we present research-based evidence in support of developing and maintaining bilingualism and biliteracy, and we submit that the empirical research support for the benefits of bilingualism and biliteracy should change language and literacy instruction. Strategies for teachers, especially teachers who do not speak the heritage language of their students, are provided and can be implemented to promote bilingual reading, writing, and language skill development.
\end{abstract}

Keywords: Bilingualism, biliteracy, cognitive benefits, heritage language (HL) loss and maintenance, teaching strategies for HL.

\section{INTRODUCTION}

An understanding of the importance bilingualism, biliteracy, and heritage language (HL) maintenance is essential for parents, educators, and policy makers, both due to a growing number of linguistically diverse students in the United States and due to the significant research in the field that supports the benefits for students, families, and students' English-language development. Public schools in the United States served 4.7 million English Language Learners (ELLs) in 2010-2011 (National Center for Education Statistics, 2013). These students often have no access to quality education (Anyon, 2005; Orfield \& Lee, 2004), which helps to explain the stable achievement gap of about 40 points between ELLs and native English speakers in the $4^{\text {th }}, 8^{\text {th }}$, and $12^{\text {th }}$ grades (National Center for Education Statistics, 2013). In addition to lower academic performance, ELLs' high dropout rate and low college enrollment numbers also suggest that schools are failing to educate culturally and linguistically diverse students (Flores et al., 2007; Giambo, 2010; Romo, 2013). Many of these multilingual students not only struggle with developing substantial academic English proficiency but also experience the three-generational language shift resulting in the loss of the HL (Fishman, 1991).

Research of the past decades has focused on the consequences of HL loss and maintenance in relation to parents' attitudes and their role in language and cultural identity maintenance as well as in families' literacy practices in the HL (Cho, 2008; Elias \& Lemish, 2008; Hashimoto \&

*Address correspondence to this author at the Florida Gulf Coast University, Fort Myers, FL, USA; Tel: 239-590-7814; Fax: 239-590-7801; E-mail; dgiambo@fgcu.edu
Lee, 2011; Joo, 2009; Rydin \& Sjoberg, 2008). However, research also suggests that a lack of support from schools, communities, and the society often jeopardizes parents' efforts for maintaining the HL (Nesteruk, 2010). Often, schools fail to provide assistance for students' developing bilingualism for numerous reasons, including: (1) lack of or inconsistencies in funding for effective bilingual programs (Gándara \& Rumberger, 2009), (2) the sole and dominant focus on the development of English proficiency, which can be a result of high-stakes testing pressures (Menken, 2013; Menken \& Solorza, 2014), and (3) teachers and district professionals' misconception of the value of being bilingual and biliterate (Cho et al., 2012). Teachers who believe that students' HL skills might interfere with the acquisition of a new language might exclude students' HL from the classroom and discourage students and families from using it (De Angelis \& Dewaele, 2009). Ultimately, this wellintended, but strongly misleading, deficit approach to becoming bilingual jeopardizes students' cognitive, linguistic, and affective development (Cho, et al., 2012; DeJong \& Harper, 2005).

The purpose of this paper is to provide an overview of the empirical evidence for the importance of bilingualism and biliteracy, to demonstrate the interrelatedness of bilingualism and biliteracy, and to outline the benefits of HL development on English language and literacy skills. Based on this evidence, we offer an array of strategies for teachers to affirm, improve, and maintain students' HL in the classroom, even when the teachers do not speak the HL of the students. Support from teachers in this manner will ultimately contribute to students' bilingual and biliteracy development, including stronger and more efficient skill development in English. 


\section{COGNITIVE IMPORTANCE OF STRENGTHENING AND MAINTAINING BILINGUALISM}

In many classrooms and schools within the United States, the overarching language goal is to develop skills in English, often to the exclusion of the development or maintenance of other, present languages. This happens in spite of the evidence in support of the benefits of bilingualism and often relies on simple immersion in an English-speaking environment. However, if the goal of school personnel is to promote language development in English, which is a new language for a growing number of students in the United States, this can most easily be accomplished when a child has proficiency in the HL, as concepts and language skills transfer from the HL to the new language (Cummins, 2005). There is evidence that the two languages both depend on one another (Bialystok, 2007; Cummins, 2005) and influence one another (Cummins, 1979; Valdes, 2005). Furthermore, HL acquisition results in facility with the HL structures (i.e., syntax, phonology, and vocabulary) as well as the ability to acquire second language structures (Mayberry, 2007). With support in the HL and the transfer of skills from one language to another, development in both languages as well as growth in academic concepts and skills can be achieved.

The importance of maintaining and developing more than one language is apparent in recent research on the effects of bilingualism in the brain, especially for children. Essentially, this research shows cognitive advantages in bilingual individuals. A bilingual person enjoys more cognitive flexibility compared to a person who is monolingual (Bialystok, 2007, 2010). Specifically, in a bilingual brain, both languages are active, even when the person is only using one of the languages in a monolingual context. Therefore, accessing language requires a competition between languages and the individual's ability to make appropriate linguistic selections. Thus, although a bilingual child may initially have some deficit in vocabulary in both languages, compared with monolingual peers, they have the benefit of stronger cognitive control, which is demonstrated through some advantages in executive function and seems to be a result of their practice and facility moving between the languages (Barac \& Bialystok, 2012; Bialystok, 2010; Bialystok et al., 2010). Furthermore, these advantages in executive function seem to be present in children as young as 2 years old (Poulin-Dubois, Blaye, Coutva, \& Bialystok, 2011). In addition to advantages in executive function, bilingual children have also been shown to have advantages over monolingual children with working memory, especially when the tasks involve executive function (Morales, Calvo, \& Bialystok, 2013). Recently, there is some indication that executive function control is not limited by socioeconomic status (Engel de Abreu et al., 2012). Thus, bilingual children benefit from increased cognitive control in executive function as compared to monolinguals, and this is apparent for children as young as 2 years of age and children from households with lower income.

\section{THE ADVANTAGES OF BILITERACY ON LAN- GUAGE AND LITERACY DEVELOPMENT IN BOTH LANGUAGES}

As has been established, language skills transfer between languages, and proficiency in the HL facilitates language and concept development in the new language (Cummins, 2005).
Similarly, this section focuses on the research that shows that language and literacy skills in one language support and facilitate the development of literacy skills in another language.

Recently, empirical research indicates that bilingual children demonstrate some advantages in early literacy skills in both languages. More specifically, bilingual children seem to have a stronger general understanding of literacy and print systems, especially when the two languages have similar writing systems. Furthermore, when the two languages have similar writing systems, children's strategies and abilities in one language, such as with decoding and phonological awareness, transfer to the other language. Thus, literacy skills in one language are enhanced by literacy skills in the other language (Bialystok et al., 2005). Furthermore, young children with stronger proficiency in both languages demonstrate stronger phonological awareness skills, most significantly for the most challenging phonemic awareness tasks, such as phonemic segmentation (Verhoeven, 2007). Therefore, strength in both languages benefits bilingual children in gaining early literacy skills, especially when the two languages have similar writing systems.

This recent research supports the National Literacy Panel on Language-Minority Children and Youth's rigorous and extensive synthesis of empirical research studies that involved children aged 3 to 18 and which were published between 1980 and 2000. This synthesis involved 4 years of work by a panel composed of 13 experts "in second language development, cognitive development, curriculum and instruction, assessment, and methodology" (August et al., 2009). The work was supported by the Institute for Education Sciences in the United States Department of Education, the National Institute for Child Health and Human Development, and the Office of English Language Acquisition (August \& Shanahan, 2006). The results reveal a significant body of empirical evidence showing interaction between languages in the development of literacy skills in bilingual students. In this discussion, for ease of explanation, we will refer to English as the new or target language, as this is the case for ELLs in the United States.

Students who demonstrate strong oral proficiency development in the second language have an associated strength in reading comprehension skills. More specifically, "vocabulary knowledge, listening comprehension, syntactic skills, and the ability to handle metalinguistic aspects of language [such as providing definitions of words] are associated with reading comprehension" (August \& Shanahan, 2006, p. 14). While teachers could logically expect that stronger oral skills in English would be associated with stronger reading comprehension in that same language, this finding provides a brick in the path to understanding how language and literacy are intertwined. Clearly, this finding points in the direction of developing students' oral English skills in the United States as a means to improving their English reading comprehension.

Another important finding of the panel indicates the significance of developing literacy skills in the HL as a means of contributing to English-language literacy development. The panel found that some facets of literacy development in English ("e.g., word and pseudoword reading, cognate vocabulary, reading comprehension, 
reading strategies, spelling, and writing (August \& Shanahan, p. 14)") are interconnected to similar skills in the HL. The panel concluded that literacy skills in English are at least somewhat related to literacy skills in the HL). Specifically, regarding the development of spelling skills in English, stronger skills in certain aspects of early literacy in the HL, such as phonological awareness, phonological recoding, and phonological memory, influence students' English spelling skill development, regardless of the type of writing system in the HL (August \& Shanahan, 2006).

More generally, the panel found that better student literacy performance results from reading and using material in the language that is stronger for the students (August \& Shanahan, 2006). They assert that, given the results of the body of extant literature regarding the transfer of some literacy skills between languages, literacy instruction for students who have developed literacy skills in their HL should build on skills in the HL so that these skills will then transfer into English. The panel recognized the advantage that language-minority students have in English literacy when they are literate in the HL. Furthermore, they found that language-minority students who receive literacy instruction in their HL as well as in English demonstrated better performance in English reading than did languageminority students who received instruction only in English. This held for both elementary and secondary level students (August \& Shanahan, 2006). The results of the panel's synthesis of research were strongly supportive of the advantages of developing literacy in the HL, the transferability of literacy skills to English, and the advantages in English literacy skills when the importance of biliteracy is acknowledged via demonstrated priorities in literacy instruction.

Research on the effectiveness of bilingual programs in relation to emerging bilingual children's literacy performance suggests that English language learners whose HL is supported outperformed peers who are placed in English-only immersion programs (Thomas \& Collier, 2002). In a recent study, Spanish-speaking and Cantonesespeaking second graders in transitional bilingual classrooms had equal or better scores on English decoding and reading comprehension measures than monolingual English speaking children (Uchikoshi \& Maniates, 2010). Furthermore, an analysis of literature discussions that focused in read-alouds in English in a fifth grade transition bilingual program examined the effects of a teacher's responsiveness to students' linguistic and cultural resources (e.g. allowing code-switching), and these practices resulted in students' efficient use of comprehension and metalinguistic and vocabulary strategies (Worthy et al., 2013).

The importance of biliteracy is further evidenced by the recent movement in many states to implement a seal of biliteracy, which is added to a students' diploma or transcript to recognize high school graduates who have demonstrated advanced proficiency in speaking, reading, and writing in at least one language other than English. California was the first state to implement the Seal of Biliteracy in January 2012 (i.e., California Assembly Bill 815, 2011; California State Department of Education, n.d.). The purposes of awarding the seal include promoting the development of biliteracy, recognizing the value of diversity, and providing employers and universities with a method of identifying and giving credit to those who are biliterate. The following states have adopted legislation approving a state Seal of Biliteracy: Illinois, Louisiana, Minnesota, New Mexico, New York, Washington, and Texas (by state board rule). A Seal of Biliteracy is under consideration in Massachusetts, Virginia, and Utah. The following states are in the early stages of consideration: Florida, Indiana, Maryland, Michigan, Nevada, Ohio, Oregon, and Wisconsin (Californians Together \& Velazquez Press, 2014).

\section{STRATEGIES FOR TEACHERS}

Teachers with an understating of the benefits of bilingualism and the damaging effects of HL loss are found to be more responsive to the linguistic needs of bilingual students. Research suggests that teacher preparation and professional development seem to influence teachers' attitude toward their role in promoting biliteracy skills (García-Nevarez et al., 2004; Lee \& Oxelson, 2006). Specifically, teacher education programs and in-service professional development can inform teachers of the benefits of bilingualism and biliteracy as well as provide teachers with the strategies to act on put their knowledge into practice.

Many strategies and activities can be used by teachers who do not speak the HL of their students but who recognize the power of biliteracy and strive to promote it. These include strategies that can be implemented to promote reading in both languages, writing in both languages, and language development that supports biliteracy (Szilágyi et al., 2013). Teachers can provide access to high-quality bilingual books (e.g. Santillana, Cinco Puntos Press) in different languages in the classroom. To promote reading in two languages, bilingual books may be incorporated into existing literacy activities. For example, students can summarize the books in both languages and share them in two languages at school and at home. Students can create their own dual language books as well, translating from the new language to the HL (Cummins, 2005). With either bilingual or monolingual books, students might participate in book talks (Fountas \& Pinnell, 2001) in both languages at school and at home. To ensure home and school connections, students can present this book talk to peers in English, and then present it to their parents in the HL at home. As a response, parents can write a comment or question in the HL, and students can translate the parents' feedback to the teachers and peers into English (Szilágyi, et al., 2013).

Teachers can promote writing in both languages with activities that involve individuals other than the teacher to review the work in another language (Szilágyi, et al., 2013). Paraprofessionals, parents, college students and community members who speak the given language can become involved in writing activities with students. For example, with the help of parents, students can create a "Book About Me" or books on diverse topics in their HL and share it with classmates. These books might become part of the school library where native speakers of English who learn a foreign language (e.g., Spanish) can benefit from reading these books. In addition, students might translate the school news program and provide the translation in the broadcast at school. Translating the school newsletter that is sent home to 
parents can be of help to the school community. These examples demonstrate how cognitive apprenticeship and authentic activities make students aware of the value of literacy skills in more than one language (Brown et al., 1989). Dialog journals in two languages allow the students to use the HL for journaling an experience, while the teacher provides key vocabulary in English in her response (Pappamihiel \& Lynn, 2014). Engaging in sister-class projects that involve students who speak different languages, possibly from different countries, working together on creating literature and art can serve to enhance literacy skills in both languages (Cummins, 2005). Using these strategies provides the students practice using language and literacy skills in both languages, and the exposure of the students' work to native speakers of both languages relieves the teacher of the need to understand the HL of the students (Szilágyi, et al., 2013).

Systematic use of cognates as an effective language learning strategy promotes the development of literacy skills in both languages and potentially supports students' vocabulary, reading comprehension, and spelling skills in both languages (Cummins, 2005; Nagy, Garcia, Durgunoglu, \& Hancin-Bhutt, 1993; Szilágyi, et al., 2013). Cognates are especially useful when teaching academic English. Languages often have cognates in academic vocabulary, because even languages that are not closely related (e.g. Spanish and English) borrow academic terms from Greek and Latin languages (e.g. dictatorship and dictadura, photosynthesis and fotosíntesis, geometry and geomatria). Searching for cognates when reading science or history texts might effectively and efficiently help students decode and comprehend complex reading materials with unfamiliar words. Although false cognates that might mislead a learner exist, their number is insignificant. For example, "sympathy" in English has a meaning of compassion while its false cognates both in Spanish and in Hungarian "simpatia" and "szimpatia," respectively, mean friendliness, affection, and/or kindness. Given the benefits of learning about and using cognates, the few examples of false cognates should not deter the use of cognates to enrich students' vocabulary and comprehension in both languages.

\section{CONCLUSION AND FINAL THOUGHTS}

There is significant research in the field of bilingualism and biliteracy to support the claim that there are benefits to both and that language and literacy development in one language enhances and supports language and literacy development in a new language. This knowledge base should logically change the way in which language-minority children are taught, using the development and transferability of HL and literacy skills to more effectively teach skills in the new language (August \& Shanahan, 2006). When bilingual education or HL support is not possible, teachers, who do not speak the heritage language of their students but who understand the recent research demonstrating the benefits of bilingualism and biliteracy, can implement strategies that support students' reading, writing, and language development in the heritage language.

There is some movement in education to recognize the importance of biliteracy, including the seal of biliteracy. Without diminishing the importance of such initiatives, we would like to suggest that recognizing achievement in biliteracy upon high school graduation is not enough. It would seem that recognition at the end of high school, maybe without having implemented the knowledge base from empirical research to support the development of biliteracy from early literacy skills at the start of elementary school, risks losing the opportunity to capitalize on the skills that some children bring to school and that others could develop with the support of informed teachers and parents. There are solid, research-based indications of how to build on and maintain bilingualism and biliteracy, resulting also in stronger language and literacy skills in English or in other new languages. Whether a school has the goal of preparing bilingual and biliterate students or solely focuses on English language and literacy skills, developing and maintaining bilingualism and biliteracy can bring about either result.

\section{LIST OF ABBREVIATIONS}

\section{ELL = English Language Learner \\ $\mathrm{HL}=$ Heritage Language}

\section{CONFLICT OF INTEREST}

The authors confirm that this article content has no conflict of interest.

\section{ACKNOWLEDGEMENTS}

Declared none.

\section{REFERENCES}

Anyon, J. (2005). Radical Possibilities: Public Policy, Urban Education, and New Social Movement. New York: Routledge.

August, D., \& Shanahan, T. (Eds.) (2006). Developing Literacy in SecondLanguage Learners: Report of the National Literacy Panel on Language-Minority Children and Youth. Laurence Erlbaum Associates: Mahwah, New Jersey.

August, D., Shanahan, T., \& Escamilla, K. (2009). English language learners: Developing literacy in second-language learners - Report of the National Literacy Panel on Language-Minority Children and Youth, Journal of Literacy Research, 41, 432-452.

Barac, R., \& Bialystok, E. (2012). Bilingual effects on cognitive and linguistic development: Role of language, cultural background, and education. Child Development, 83, 413-422.

Bialystok, E. (2007). Acquisition of literacy in bilingual children: A framework for research. Language Learning, 57(Suppl 1), 45-77.

Bialystok, E. (2010). Lifelong bilingualism: Linguistic costs, cognitive benefits, and long-term consequences. NIH Behavioral and Social Science Research Lecture Series, 1, 33,

Bialystok, E., Barac, R., Blaya, A., \& Poulin-Dubois, D. (2010). Word mapping and executive functioning in young monolingual and bilingual children. Journal of Cognitive Development, 11(4), 485508.

Bialystok, E., Luk, G., \& Kwan, E. (2005). Bilingualism, biliteracy, and learning to read: Interactions among languages and writing systems. Scientific Studies of Reading, 9(1), 43-61.

Brown, J., Collins, A., \& Duguid, P. (1989). Situated cognition and the culture of learning. Educational Researcher, 18(1). 32-42.

California Assembly Bill 815 (2011). Brownley, Chapter 618, Statutes of 2011. Retrieved from: http://legiscan.com/CA/text/AB815/id/ 354090

California State Department of Education (n.d.). State seal of biliteracy Retrieved from: http://www.cde.ca.gov/sp/el/er/sealofbiliteracy.asp.

Californians Together \& Velazquez Press (2014). State laws regarding the seal of biliteracy. Retrieved from: http://sealofbiliteracy.org/

Cho, J., Rios, F., Trent, A., \& Mayfield, K. (2012). Integrating language diversity into teacher education curricula in a rural context: 
Candidates' developmental perspectives and understandings. Teacher Education Quarterly, 39(2), 63-85.

Cho, S. (2008). Korean immigrants' social practice of heritage language acquisition and maintenance through technology. Dissertation. University of British Columbia. Retrieved from: https://circle.ubc.ca/bitstream/handle/2429/1018/ubc_2008_fall_ch o_sunah.pdf? sequence $=1$

Cummins, J. (1979). Linguistic interdependence and the educational development of bilingual children. Review of Educational Research, 49(2), 222-251.

Cummins, J. (2005). A proposal for action: Strategies for recognizing heritage language competence as a learning resource within the mainstream classroom. The Modern Language Journal, 89, 585592.

De Angelis, G., \& Dewaele, J.M. (2009). The development of psycholinguistic research on crosslinguistic influence. In L. Aronin \& B. Hufeisen (Eds.). The exploration of multilingualism (pp. 6377). Amsterdam: John Benjamin.

DeJong, E.J., \& Harper, C.A. (2005). Preparing mainstream teachers for English-Language Learners: Is being a good teacher good enough? Teacher Education Quarterly, 32(2), 101-124.

Elias, N., \& Lemish, D. (2008). Media uses in immigrant families: Torn between 'inward' and 'outward' paths of integration. International Communication Gazette, 70(21), 21-40.

Engel de Abreu, P.M.J., Cruz-Santos, A., Tourinho, C.J., Martin, R., \& Bialystok, E. (2012). Bilingualism enriches the poor: Enhanced cognitive control in low-income minority children. Psychological Science, 23(11), 1364-1371.

Fishman, J.A. (1991). Reversing language shift: Theoretical and empirical foundations of assistance to threatened languages. Clevedon, UK: Multilingual Matters.

Flores, B.B., Clark, E.R., Claeys, L., \& Villarreal, A. (2007). Academy for teacher excellence: Recruiting, preparing, and retaining Latino teachers through learning communities. Teacher Education Quarterly, 34(4), 53-69.

Fountas, I.C., \& Pinnell, G.S. (2001). Guiding readers and writers (grades 36): Teaching comprehension, genre, and content literacy. Portsmouth, NH: Heinemann.

Gándara, P., \& Rumberger, R.W. (2009). Immigration, language, and education: How does language policy structure opportunity? Teachers College Record, 111(3), 750-782.

García-Nevarez, A.G., Stafford, M.E., \& Arias, B. (2004). Arizona elementary teachers' attitudes toward English language learners and the use of Spanish in classroom instruction. Bilingual Research Journal, 29(2), 295-317.

Giambo, D.A. (2010). High stakes testing, high school graduation, and limited English proficient students: A case study. American Secondary Education Journal, 38(1). Retrieved from: http://static.ashland.edu/academics/education/ase/index.html

Hashimoto, K., \& Lee, J. (2011). Heritage-language literacy practices: A case study of three Japanese American families. Bilingual Research Journal, 34(2), 161-184.

Joo, H. (2009). Literacy practices and heritage language maintenance. Journal of Asian Pacific Communication, 19(1), 76-99.

Lee, J.S., \& Oxelson, E. (2006). "It is not my job": K-12 teacher attitudes toward students' heritage language maintenance. Bilingual Research Journal, 30(2), 453-477.

Mayberry, R.I. (2007). When timing is everything: Age of first-language acquisition effects on second-language learning. Applied Psycholinguistics, 28, 537-549.
Mehrabi, N. (2014). The effects of second language writing ability on HL writing ability. Theory and Practice in Language Studies, 4(8), 1686-1691.

Menken, K. (2013). Restrictive language education policies and emergent bilingual youth: A perfect storm with imperfect outcomes. Theory into Practice, 52(3), 160-168.

Menken, K., \& Solorza, C. (2014). No child left bilingual: Accountability and the elimination of bilingual programs in New York City schools. Education Policy, 28(1), 96-125.

Morales, J., Calvo, A., \& Bialystok, E. (2013). Working memory development in monolingual and bilingual children. Journal of Experimental Child Psychology, 114(2), 187-202.

Nagy, W.E., Garcia, G.E., Durgunoglu, A, \& Hancin-Bhatt, B. (1993). Spanish-English bilingual children's use and recognition of cognates in English reading. Journal of Reading Behavior, 25(3), 241-259.

National Center for Education Statistics (2013). The condition of education: English language learners. Retrieved from: http://nces.ed.gov/ programs/coe/indicator_cgf.asp.

Nesteruk, O. (2010). Heritage language maintenance and loss among children of Eastern European immigrants in the USA. Journal of Multilingual and Multicultural Development, 31(3), 271-286.

Orfield, G., \& Lee, C. (Eds). (2004). Brown at 50: King's dream or Plessy's nightmare? Cambridge, MA: Harvard, Civil Rights Project.

Pappamihiel, E. \& Lynn, A. (2014). How can monolingual teachers take advantage of learners' native language in class. Childhood Education, 90(4). 291-297.

Poulin-Dubois, D., Blaya, A., Coutva, J., \& Bialystok, E. (2011). The effects of bilingualism on toddlers' executive functioning. Journal of Experimental Child Psychology, 108(3), 567-579.

Romo, V. (2013). English language learners: Public schools' forgotten kids. Retrieved from: http://www.takepart.com/article/2013/ 06/25/english-language-learners-struggle-public-schools

Rydin, I., \& Sjöberg, U. (2008). Narratives about Internet as a communicative space for identity construction among migrant families. In I. Rydin \& U. Sjöberg (Eds.), Mediated crossroads: Identity, youth culture and ethnicity (pp. 193-214). Göteborg, Sweden: Nordic Information Centre for Media and Communication Research, Göteborg University.

Szilágyi, J., Giambo, D. \& Szecsi, T. (2013). "What if I don't speak it?" Classroom strategies to nurture students' heritage languages, Childhood Education, 89(2), 117-121.

Thomas, W.P., \& Collier, V.P. (2002). A national study of school effectiveness for language minority students' long-term academic achievement. Santa Cruz, CA: University of California-Santa Cruz Center for Research on Education, Diversity and Excellence.

Uchikoshi, Y., \& Maniates, H. (2010). How does bilingual instruction enhance English achievement? A mixed-methods study of Cantonese-speaking and Spanish-speaking bilingual classrooms. Bilingual Research Journal, 33, 364-385.

Valdes, G. (2005). Bilingualism, heritage language learners, and SLA: Opportunities lost or seized? Modern Language Journal, 89, 410426.

Verhoeven, L. (2007). Early bilingualism, language transfer, and phonological awareness. Applied Psycholinguistics, 28, 425-439.

Worthy, J., Duran, L., Hikida, M., Pruitt, A., \&Peterson, K. (2013). Spaces for dynamic bilingualism in read-aloud discussions: Developing and strengthening bilingual and academic skills. Bilingual Research Journal, 36, 311-328.

Received: September 10, 2014

Revised: December 01, 2014

Accepted: February 02, 2015

(C) Giambo and Szecsi; Licensee Bentham Open.

This is an open access article licensed under the terms of the Creative Commons Attribution Non-Commercial License (http://creativecommons.org/licenses/by-nc/3.0/) which permits unrestricted, non-commercial use, distribution and reproduction in any medium, provided the work is properly cited. 